\title{
Research
}

\section{Management Conflicts in Cameroonian Community Forests}

\author{
Driss Ezzine de Blas $^{1}$, Manuel Ruiz-Pérez $^{2}$, and $\underline{\text { Cédric Vermeulen }}^{3}$
}

\begin{abstract}
Cameroonian community forests were designed and implemented to meet the general objectives of forest management decentralization for democratic and community management. The spread of management conflicts all over the country has shown that these broad expectations have not been met. We describe conflicts occurring in 20 community forests by types of actors and processes involved. We argue that a number of external (community vs. external actors) and internal (intra-community) conflicts are part of the causes blocking the expected outcome of Cameroonian community forests, fostering bad governance and loss of confidence. Rent appropriation and control of forest resources appear as systemic or generalized conflicts. While community forest support projects have tended to focus on capacity building activities, less direct attention has been given to these systemic problems. We conclude that some factors like appropriate leadership, and spending of logging receipts on collective benefits (direct and indirect) are needed to minimize conflicts. Government and development agencies should concentrate efforts on designing concrete tools for improving financial transparency while privileging communities with credible leaders.
\end{abstract}

Key Words: Cameroon; common pool resources management; community forests; network analysis; social conflicts

\section{INTRODUCTION}

Forest decentralization reforms were part of a larger reform process concerning developing states and former socialist economies whose aim was to improve efficiency, equity, and political participation after the economic crisis in the 1980s (OECD 1997, Ribot et al. 2006). Allocation of new forest management rights to local user groups after decentralization reforms triggered conflicts worldwide. In Bolivia, decentralization reforms dramatically changed the power asymmetry of actors with a history of land competition (de Jong et al. 2006). This allowed local actors to access rights that have empowered their participation in forest management, but also facilitated their appropriation by local elites and triggered conflicts for the control of forest resources (Pacheco 2005). Kumar (2002), Adhikari et al. (2004), and Iversen et al. (2006) report how local social elites captured forest environmental services following local forest management implementation in India and Nepal. Siswanto and Wardojo (2005) showed that land tenure conflicts persist between central and local governments and communities in Indonesia, leading to social conflicts and forest mismanagement. Azhar (1993) and Iversen et al. (2006) identified rent seeking behavior, facilitated by imprecise regulations, as one main obstacle to achieving common forest management. We understand rent seeking behavior as a predatory redistribution of economic benefits by the social actors detaining the power to do so (Krueger 1974, Buchanan et al. 1980, Magee et al. 1989).

This emerging literature leads to the assertion that the devolution of formal rights of forest management to areas containing actors with asymmetric political and economic power inevitably leads to management conflicts (Colfer and Capistrano 2005). Moreover, the way forest rights have been devolved guarantees that the state will continue to play a significant role, thus opening the door for potential conflicts (Larson et al. 2010). We define conflict as the clash of interests in a particular process, e.g., decision making, control of environmental services, information sharing, involving at least two actors with different interests 
and concrete goals (Knight 1992). The outcome will depend on the actors' de facto and de jure power to enforce their goals (Crozier and Friedberg 1977, Mermet et al. 2005).

Acknowledging the limited effect that mere legal reforms had to maximize the expected outcomes of forest decentralization, the academic community has moved the discussion and theorizing from decentralization to governance and accountability paradigms (Ribot et al. 2006, Tacconi 2007). Research works referring to collective action and management of common pool resources have also enriched the debate on how institutions and contextual factors influence success (Ostrom 1990, Turner 1999, Wollenberg 1998). Literature reviews in the same field have highlighted the need for comparative studies based on a large number of case studies (Agrawal 2001, Larson 2005, Larson et al. 2010).

In Cameroon, community forests were implemented after the 1994 new Cameroonian Forestry Law. This reform was the result of both political and economic driving forces (Brunner and Ekoko 2000). Decentralization was one of these drivers, under the assumptions of improving livelihoods by increasing monetary revenues, village infrastructures, forest self-management empowerment, and rural employment (Logo 2003). The decentralization reform also affected political structures and economic sectors such as the regional administration council and finance functioning (World Bank 1998, Cheka 2007).

The literature on Cameroonian community forest decentralization conflicts has focused on analyzing specific case studies (Assembe 2003, Etoungou 2003) or general institutional dynamics (Logo 2003). Oyono et al. (2006, 2007) pushed the debate on management conflicts in Cameroonian community forests in another direction. Drawing on a few case studies in southern Cameroon, this work has generated a narrative of management conflicts and governance indicators. In the present paper, we extend the conflict analysis of these authors with a comparative study of 20 community forests. We distinguish between structural conflicts, which are embedded in the design of the law (Cheka 2007), normally linked to territorial and financial appropriation processes and also described as conflicts of discourse (Oyono 2005), and implementation conflicts, which emerge during the development of community forests (Oyono et al.
2006, 2007). Although we acknowledge possible links between structural and implementation conflicts, we prefer a bottom-up field based analysis, through a comparative study of implementation conflicts, where the interactions among social actors can be explored. In the present paper, we describe such conflicts and conduct a comparative analysis to understand which factors minimize them as well as their influence in constraining the potential of community forests for poverty alleviation.

First, we outline the structural deficiencies of the 1994 Cameroonian Forestry Law concerning decentralization and community forest design to explain the difference between structural and implementation conflicts. In the methods section, we describe the geographic location of the community forests sampled and the statistical and network analysis we performed. In the results and discussion section, we describe how the logging rent is invested, what types of implementation conflicts occur, and which actors are involved. Finally, we explore which factors minimize community forest management conflicts. These results enabled us to outline possible strategies to overcome such a socially suboptimum outcome.

\section{The two sides of the Cameroonian forest decentralization process}

As noted above, one of the main policy characteristics of the 1994 Cameroonian Forestry Law reform was decentralization. A number of new forest rights were granted to local villages, mainly by means of two measures: first, the decentralization of $40 \%$ of taxes levied from Forest Management Units, i.e., logging concessions, to municipalities and $10 \%$ to local villages; and second, by granting property rights of communal forests to municipalities and the rights of use of community forests to local villages. Indeed, local villages are entitled by law to use and sell all types of forest resources although in practice, the main application of community forests has been commercial logging (Logo 2003).

Nevertheless, a different reading of the decentralization process emerges from a political economy perspective, highlighting the existence of a "recentralization" strategy (Ezzine de Blas et al. 2009), also described as 'conflict of discourse' (Oyono 2005): behind the official allocation of new 
forest rights to rural populations there are countless political and economic actors who put their priorities above the design of an efficient devolution process (Brunner and Ekoko 2000). A first indicator is the present zoning of Cameroonian forests that were divided by the 1994 Forestry Law into a Permanent Forest Domain (PFD) and a Non Permanent Forest Domain (NPFD). The PFD comprises permanent forests under government ownership and managed by the Ministry of Forests. Communal forests are established in the PFD and managed by the municipality; its forests are protected by law and no conversion to other land uses is allowed. The NPFD comprises nonpermanent forests under the jurisdiction of the Ministry of Agriculture; forests in the NPFD can be legally converted to nonforest uses. Community forests in Cameroon can only be allocated in NPFD, with a maximum area of 5000 ha, under the jurisdiction, monitoring, and control of the Ministry of Forests. The area designated as community forest was thus not concerned by direct taxation of logging rights in the PFD but represented a strategy for the Ministry of Forests to monitor logging activities and to 'capture' part of the territory under the jurisdiction of the Ministry of Agriculture (Karsenty 2006).

In practice, the PFD was decreed over large areas containing forests with high logging potential, whereas the NPFD was normally restricted to already logged forests, or degraded areas close to roads and logging tracks. The PFD consequently systematically overlapped with forest areas where locals have enjoyed de facto traditional rights of use for centuries (Vermeulen 1997) creating a source of tension (Emerit and Lescuyer 2003, Geschiere 2004). This appropriation of forest and territory driven by government institutions is a structural conflict that is embedded in the design of the Forestry Law reform.

A second structural conflict is downward accountability: $50 \%$ of logging Forest Management Units (FMU) tax has been decentralized and now targets municipalities and local villages with the aim of reducing poverty and achieving development objectives, but there are no appropriate accountability mechanisms embedded in the 1994 Forestry Law and its decree ${ }^{[1]}$ (Cerutti and Tacconi 2006). In an already centralized government like that in Cameroon, where mayors are held accountable to the upper government hierarchy but not to the local population who elected them, no mechanisms were planned to foster downward transparency from the government to local populations after logging taxes came under the control of municipal council. Consequently, the respective $40 \%$ and $10 \%$ FMU taxes that were decentralized to municipalities and local villages have frequently been appropriated by rural political elites (Etoungou 2003, Logo 2003, Oyono et al. 2006). A third structural conflict has its source in the alternation of logging specifications. Whereas the 1995 decree stated that community forests could use heavy machinery for industrial logging, a ministerial letter in $2001^{[2]}$ forbade it. The latest manual of procedures for guiding community forest exploitation practices published in 2009 (MINFOF 2009) again authorizes the use of light machinery to open logging tracks. Finally, the 1994 Forestry Law interprets "community" as a homogeneous group of forest users relating to power and land tenure, bypassing the reality of local forest tenure, which is mainly composed of adjacent spaces owned by different families with unequal historical rights (Geschiere 2004). Following Oyono (2005), this could again be described as a 'conflict of discourse' between the state and rural forest groups.

In addition to these structural conflicts, a number of implementation conflicts also occur (Cuny et al. 2004, Oyono et al. 2006, Julve et al. 2007, Oyono et al. 2007). They relate to different aspects of the development and implementation of a forest management plan, including the lack of local technical skills; conflicts of interest between different village actors concerning forest management decisions; delimitation disputes between neighboring villages; and contract disagreement with timber buyers or logging companies who sublet the community logging rights. In the coming sections, we explore the underlying typologies of these implementation conflicts through innovative mapping techniques, and discuss what conditions are needed to minimize them.

\section{METHODS}

We sampled 20 community forests stratified to include Cameroonian provinces and forest biomes in the lowland humid and mountain tropical forests, where community forests have undergone the most intense development. At the time of the survey (2006), they corresponded to $45 \%$ of all approved community forests that were being actively 
Fig. 1. Sampled community forests and Cameroonian Permanent Forest Domain.

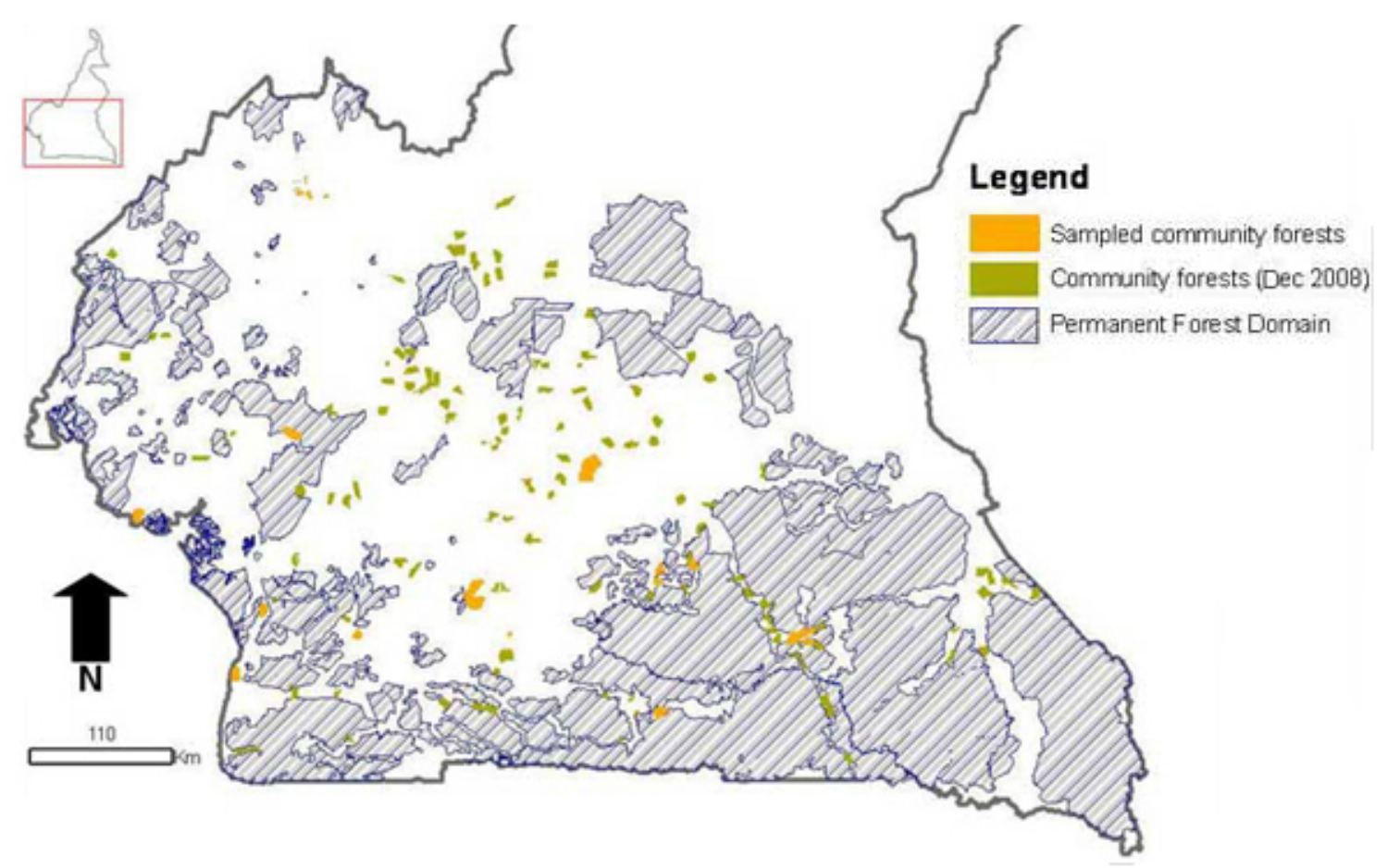

exploited. Figure 1 shows the community forests legalized in December 2008. "Legalized" means that the area of the community forest has been accepted by the Ministry of Forests. The procedures for obtaining a simple management plan and cutting authorization come afterward. Also shown are the sites sampled and the area of Permanent Forest Domain within the tropical humid forest zone in Cameroon.

To understand how commercial logging has financially and physically benefited community forest populations, we recorded the type of benefits obtained by community forest members through the logging rent. These benefits are managed by the Management Committee after the timber is sold. We classified community forest members' benefits as direct, or as in-kind and indirect when the economic benefits of logging were invested in village collective facilities. In our sample, there was no direct distribution of money. We also checked the benefits in the field. For instance, we asked teachers if they had been paid by the Management Committee. Other investments like schools, housing improvement, houses for community activities, etc. were recorded and their cost triangulated with different sources, i.e., management committees, experts, commercial groups. Conflicts affecting community forests were recorded based on the legal limits of the community forest as our main object of study. When a community forest group interacts with an external actor, this can lead to an external conflict. If the interaction is among actors belonging to the community that holds a given community forest, it can lead to an internal conflict (Table 1). For the identification of internal actors, i.e., within the community forest, we selected representatives of the Management Committee and the community forest user groups outside it. This decision was taken based on the forest law decree [3] that regulates the need for a Management Committee to legally represent the community forest. The Management Committee can be an association or a Community Interest Group (Groupe 
d'Interêt Communautaire). The Management Committee is composed of at least four people: the president, the secretary, the finance administrator, and the delegate of logging operations. It is responsible for all activities related to forest management: development of the forest management plan, called Simple Management Plan in the manual of procedures; negotiation of a stumpage fee with an industrial operator or self-management of logging activities; investment of benefits in collective facilities and services (see Ezzine de Blas et al. 2009 for more details of how management works). Because associations are legally prohibited from undertaking profit-making operations, Management Committees have usually preferred to be legally recognized as a Community Interest Group. Internal conflicts were recorded as confrontations between the Management Committee and forest users outside it. Beyond the difference between external and internal, conflicts were also defined and typified by the actors involved (Table $1)$.

For each community forest, the first data sample on what kinds of conflicts were occurring was collected through personal semistructured interviews with the two main actors within the community forest. This facilitated the identification of contrasting views among internal actors. A second consolidated matrix was completed through interviews with experts in the study regions to check the accuracy of the data.

To explore the conditions that minimize conflicts, we applied Wollenberg's (1998) and Agrawal's (2001) schemes of variables that facilitate sustainable governance of resources. All data were codified to produce a matrix of quantitative, ordinal, and categorical variables (Table 2).

Variables were analyzed using descriptive and statistical nonparametric tests, multivariate (Categorical Principal Components Analysis) and network analysis. Multivariate analyses were performed using SPSS 17.0 while network analysis used Ucinet software. In the present paper, we use a 2-mode network analysis to graphically represent the links between conflicts and actors. A more detailed description of such analysis is given in the next section.

\section{RESULTS AND DISCUSSION}

\section{Conflict typologies}

A total of 10 conflicts were identified, six external and four internal. Figure 2 presents their frequency in the sample.

The most frequent external conflicts related to the corruption of the forest administration and the nonrespect or difficulty involved in setting up a logging contract with an industrial operator. Problems of delimitation between neighboring villages were less common in the sample. The least frequent conflicts were delimitation problems with timber FMUs or with Sales of Standing Volume (SSV) and specific situations in which the International Cooperation Agency-Non Governmental Organization (ICA-NGO) strategy to support the community forest did not receive the full agreement of its members.

Internal problems frequently concerned the sale of undeclared timber, mismanagement of logging benefits by the Management Committee, and confrontations between the Management Committee and other community forest groups to control forest management decisions. Lack of technical and/or human capacities were infrequent sources of conflict.

We define the more widespread external and internal conflicts, i.e., those that occurred in $50 \%$ of the sample, as systemic conflicts. They indicate chronic constraints in the implementation of community forestry in Cameroon. We define less frequent conflicts, such as overlap with other types of forest management units and failure of partnerships with ICA-NGO, as local or site specific conflicts.

Conflict frequency is the first estimation of which conflicts play a major role in shaping community forest social interactions. We can further explore the relationship between conflicts and the community forests sampled through network analysis, which enables the identification of core vs. periphery conflicts and connected vs. isolated problems. Conflicts positioned at the centre of the network play a more important role in blocking the full potential of the process, whereas those situated in the periphery are less relevant. 
Table 1. Description and classification of conflicts.

\begin{tabular}{|c|c|c|c|}
\hline \multicolumn{2}{|c|}{ External to the community forest } & \multicolumn{2}{|c|}{ Internal to the community forest } \\
\hline Actor & Type of conflict & Actor & Type of conflict \\
\hline \multirow[t]{3}{*}{ 1- Logging operator } & 1-1 zoning overlap with a concession & $\begin{array}{l}\text { 5- Management } \\
\text { institution }\end{array}$ & $\begin{array}{l}\text { 5-1 Mismanagement of logging } \\
\text { benefits }\end{array}$ \\
\hline & 1-2 overlay with SSV† & & $\begin{array}{l}\text { 5-2 Lack of human or/and } \\
\text { technical capacities }\end{array}$ \\
\hline & $\begin{array}{l}\text { 1-3 no agreement / no respect of the } \\
\text { agreement by the logger }\end{array}$ & & \\
\hline $\begin{array}{l}\text { 2- Neighboring } \\
\text { villages }\end{array}$ & $\begin{array}{l}\text { 2-1 Community forest delimitation } \\
\text { disagreement with neighboring villages }\end{array}$ & $\begin{array}{l}\text { 6- Stratified social } \\
\text { groups (by age, } \\
\text { wealth, gender) }\end{array}$ & $\begin{array}{c}\text { 6-1 Struggle for control of } \\
\text { management decisions } \\
\text { 6-2 Selling of illegal local timber }\end{array}$ \\
\hline 3- ICA-NGO $\ddagger$ & $\begin{array}{l}\text { 3-1 Intervention of ICA-NGO } \\
\text { criticized by the community }\end{array}$ & & \\
\hline $\begin{array}{l}\text { 4- Forestry } \\
\text { administration }\end{array}$ & $\begin{array}{l}\text { 4-1 Need to 'motivate' government } \\
\text { officials (bribes) }\end{array}$ & & \\
\hline
\end{tabular}

$\dagger$ Sales of Standing Volume: small permits of a maximum of 2000 ha of forest, where all timber can be removed without the need of a sustainable management plan.

\$ International Cooperation Agency-Non Governmental Organization

As expected from the frequency distribution, external conflicts located at the center of the network were corruption of government officials and contract failures with loggers. Periphery conflicts were problems involved in delimiting the forest management unit and failed interventions by the ICA-NGO. These peripheral conflicts were limited to a small area and tended not to occur simultaneously in the affected communities (Fig. 3).

Network central internal conflicts concerned timber logged outside the management plan, mismanagement of logging rent, and struggles for the control of community forest management decisions. Technical deficiencies appeared as a periphery conflict, affecting in particular two community forests with no other sources of internal conflicts (Fig. 4).

\section{Perceptions of conflicts}

Data gathered during interviews with the Management Committee and groups outside it were analyzed to assess contrasting perceptions of conflicts. This enabled us to identify what constrains community forest management with the aim of identifying potential internal divisions. Figure 5 represents the total frequency of conflicts by Management Committee and forest user groups who do not belong to it, i.e., outside-inside the Management Committee.

We identified two main groups of conflicts: those perceived with a similar frequency by both groups (plotted close to the diagonal), and those perceived differently. Within the first group were low frequency conflicts, i.e., a total score less than four 
Table 2. Descriptive statistics of the variables analyzed to explore community forest governance.

\begin{tabular}{|c|c|c|c|c|c|}
\hline Variable & Type & Mean & $\begin{array}{l}\text { Standard } \\
\text { deviation }\end{array}$ & Minimum & Maximum \\
\hline Ratio between invested and MI logging benefits & Quant & .24 & .31 & 0 & 1 \\
\hline Overlay with FMU $+\pi$ & Ord & .15 & .37 & 0 & 1 \\
\hline Overlay with SSV $\mathrm{SV}^{\dagger \#}$ & Ord & .10 & .31 & 0 & 1 \\
\hline Disagreement with industrial $^{\dagger}$ & Ord & .55 & .51 & 0 & 1 \\
\hline Delimitation between villages ${ }^{\dagger}$ & Ord & .30 & .47 & 0 & 1 \\
\hline Disagreement with ICA-NGO ${ }^{\dagger}$ & Ord & .10 & .31 & 0 & 1 \\
\hline Corruption of government officials ${ }^{\dagger}$ & Ord & .40 & .50 & 0 & 1 \\
\hline Mismanagement ${ }^{\dagger}$ & Ord & .69 & .48 & 0 & 1 \\
\hline Struggle for control of management decisions ${ }^{\dagger}$ & Ord & .60 & .50 & 0 & 1 \\
\hline Technical deficiencies ${ }^{\dagger}$ & Ord & .25 & .44 & 0 & 1 \\
\hline Illegal timber ${ }^{\dagger}$ & Ord & .75 & .44 & 0 & 1 \\
\hline Demographic pressure & Ord & 1.95 & .69 & 1 & 3 \\
\hline Logging commercial potential ${ }^{\ddagger}$ & Ord & 1.75 & .68 & 1 & 3 \\
\hline Strength of local institutions ${ }^{\sharp}$ & Ord & 1.30 & .47 & 1 & 2 \\
\hline Objectives of resource management ${ }^{\S}$ & Cat & 1.94 & .25 & 1 & 2 \\
\hline Appropriate leadership & Ord & 1.25 & .44 & 1 & 2 \\
\hline Incentives to local people & Ord & 1.30 & .47 & 1 & 2 \\
\hline Coherence of interests & Ord & 1.40 & .50 & 1 & 2 \\
\hline
\end{tabular}

$\dagger$ yes $=1 ;$ no $=0$

$\$ 1=$ low; $2=$ medium; $3=$ high

$\S 1=$ commercial logging; $2=$ conservation

| 1=non; $2=$ appropriate

II Forest Management Unit

\# Sale of Standing Volume

Quant.: Quantitative; Ord.: Ordinal; Cat.: Categorical

FMU: Forest Management Units

SSV: Sales of Standing Volume

ICA-NGO: International Cooperation Agency-Non Governmental Organization 
Fig. 2. Frequencies of external and internal conflicts. SSV=Sales of Standing Volume; NGO-ICA=Non Governmental Organization-International Cooperation Agency.

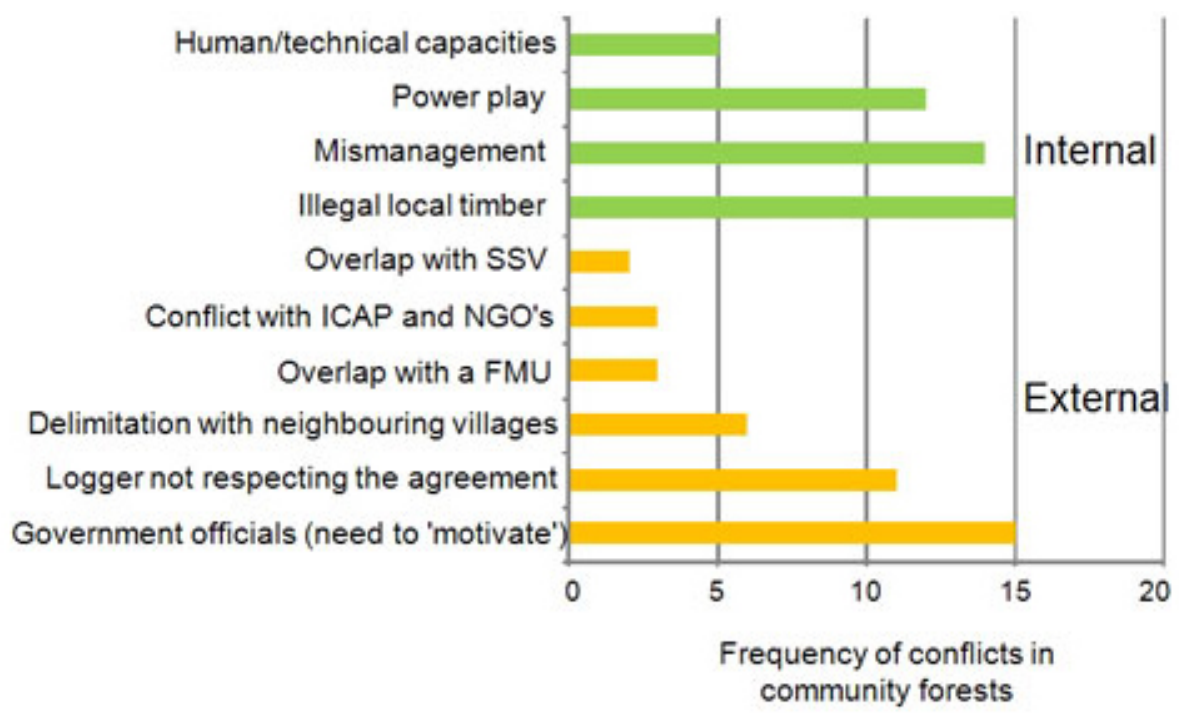

(disagreement with ICA-NGO, overlap with Sales of Standing Volume, and overlap with concession) and a group with medium frequency, i.e., a total score less than 10 (corruption of government officials, technical deficiencies, delimitation between villages, and illegal sale of timber).

The conflict most frequently identified by the Management Committee was disagreement with loggers, i.e., those who buy or actually log the timber. This is explained by the fact that the members of the Management Committee drive logging contract negotiations, while forest users not belonging to it are not always aware of what is happening. Conflicts more frequently identified by groups outside the Management Committee were mismanagement and the struggle for control of management decisions. For these conflicts, differences in the perception between the Management Committee and groups not belonging to it were statistically significant (Chi-square $\mathrm{p}<0.001$ for mismanagement and Chi-square $\mathrm{p}=0.01$ for control of management decisions). The different way these conflicts are perceived indicates a lack of trust between the inhabitants of community forests and the Management Committee. It also shows that the Management Committee may have not revealed to the researchers what was really happening for obvious reasons. In both cases, mistrust among community forest members reduces confidence in governance and management, ultimately eroding the potential of logging benefits to fully contribute to poverty reduction.

\section{Investing logging benefits}

Logging offers direct (monetary and in-kind) and indirect (improvement of collective village services) benefits to community forest user groups. Because the logging rent is managed by the Management Committee of each community forest, monetary benefits relate here to the money directly earned by community forest members when they are paid for participating in logging operations, i.e. inventorying, carrying, or sawing timber (Ezzine de Blas et al. 2009). In-kind benefits are goods distributed to all families, e.g., roofs for houses; indirect benefits are improvement of collective facilities, e.g., schools, wells, etc. These benefits were at the core of community forest design and implementation objectives. The investments of logging net benefits in monetary, in-kind, and indirect benefits, e.g., goods, infrastructure etc., are decided by the Management Committee. Therefore, forest user groups benefit from these goods only 
Fig. 3. External conflicts network analysis. Circles are sampled community forests. Squares represent conflicts. Outliers 11 and 12 are community forests in which no external conflicts were recorded.

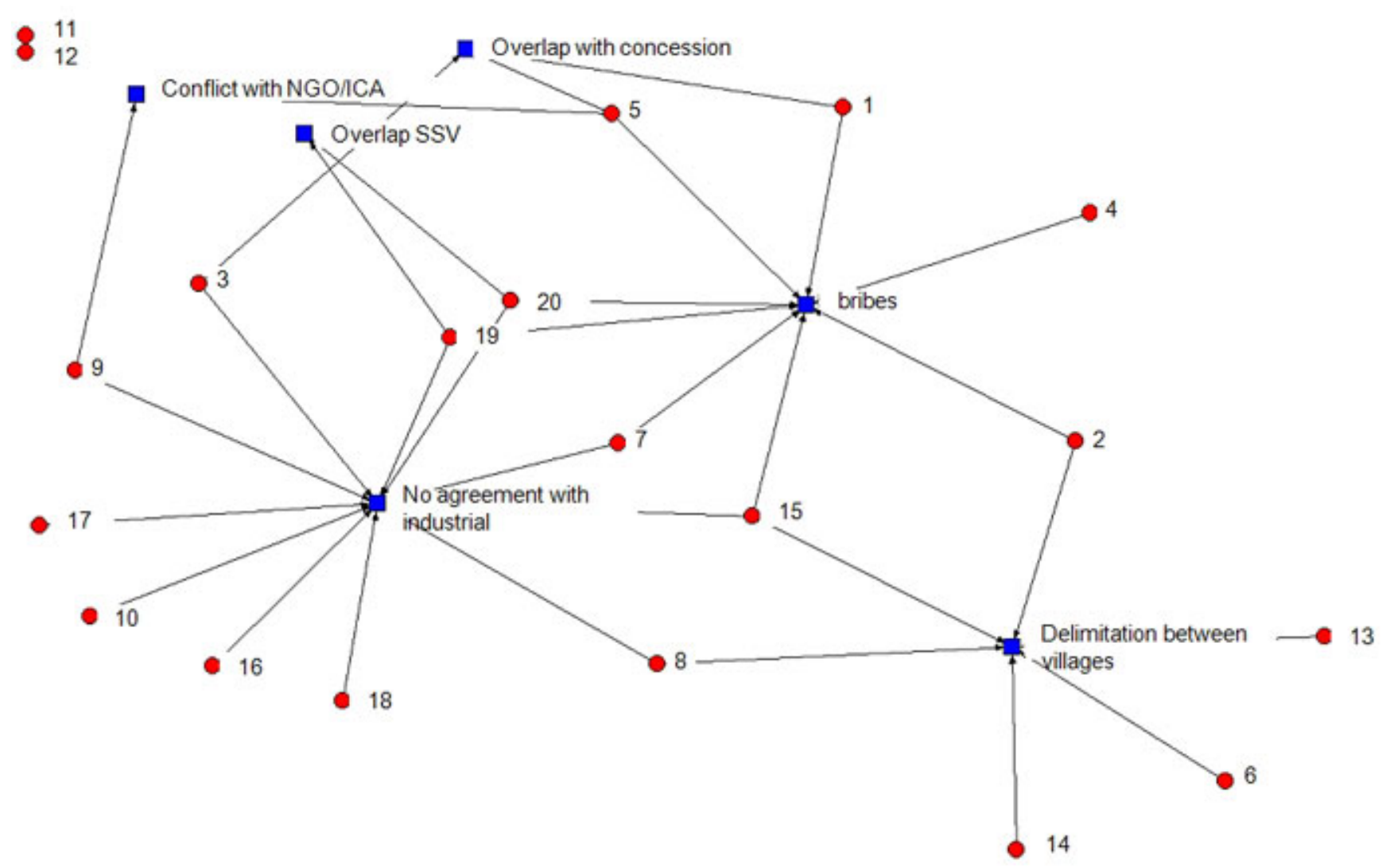

after the Management Committee invests the money earned from commercial transactions (Ezzine de Blas et al. 2009).

When the logging rent was invested in direct, inkind, or indirect, i.e., community development projects, benefits, these corresponded to basic needs such as housing, education, and improved transportation (Fig. 6). Educational services refer to the building or rehabilitation of schools, payment of teachers' salaries, and grants for students. Housing refers to direct in-kind payment made to all families belonging to the community forest, mainly roofs. Such choices indicate that logging monetary benefits are invested in basic assets, to compensate for the lack of financial capital to improve living standards. Forest management appears as just another way, perhaps the only way in the communities we sampled, to capitalize community forest households.

Health and investment in production or trade-related activities were the least frequent investments. This is because of the extensive use of traditional health systems that do not require a strong infrastructure, the difficulty in funding qualified health staff, and the difficulty in finding and supporting long-term income-generating activities in villages further from the classical subsistence or small scale commercial agriculture.

When monetary benefits from logging were not invested in shared collective benefits, based on the answers given by the interviewees, we noted that it 
Fig. 4. Internal conflicts network analysis. Circles are community forests sampled. Squares are conflicts. Outlier 16 corresponds to a community forest in which no internal conflicts were recorded.

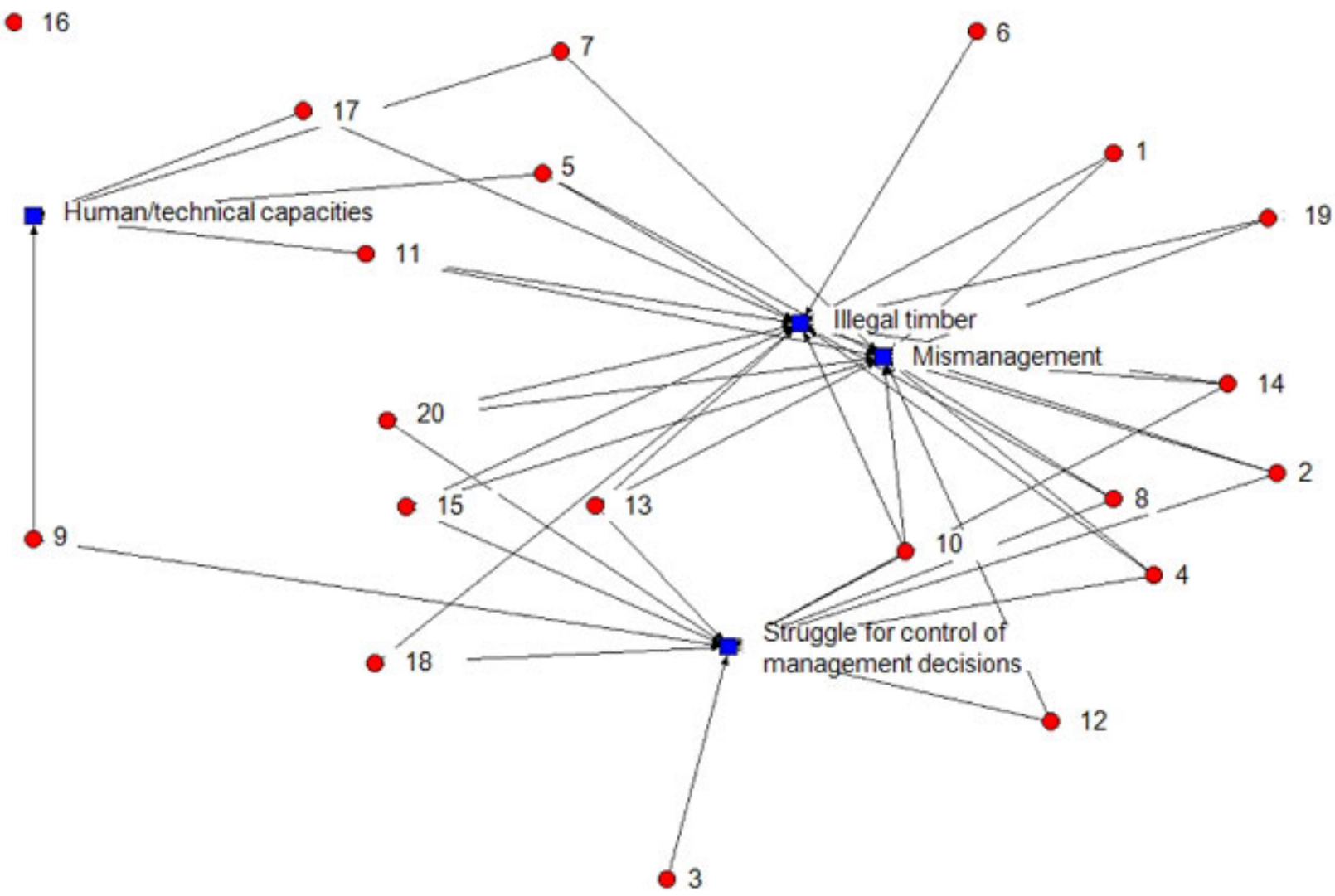

was distributed among specific actors within the villages of the community forest. This lack of downward accountability may be proof of the capture of logging benefits by local elites, which leads to intra-community conflicts, as described in a few detailed case studies in the East and South provinces of Cameroon (Assembe 2003, Logo 2003).

Data on timber production volume, timber market prices, and production costs enabled us to estimate community forest monetary benefits (Ezzine de Blas et al. 2009). In the community forests we sampled, no monetary benefits were redistributed among families. All monetary benefits were spent by the Management Committees on direct or indirect benefits for the members of the community forest. Management Committee expenditures were quantified based on the records shown in figure 6 . Oyono et al. (2006) explain that a perfectly accountable community forest management committee should spend money in a transparent way, informing and justifying to all stakeholders the choices made. In the community forests sampled, the simple management plan specifies that money should be spent on a number of direct shared investments, for each family, as well as on collective facilities. To check this, we assessed the ratio of investment in collective benefits to total logging net revenues as an indication of the degree of Management Committee downward accountability. The investment ratio was generally very low. On average, it represented $24 \%$ of total net revenues. In detail, out of the total sample, 12 community forests invested less than $25 \%$ of their total benefits, from which eight did not invest any money in the 
Fig. 5. Perceptions of conflicts by the Management Committee and community forest users not belonging to it. FMU=Forest Management Units; SSV=Sales of Standing Volume; NGO-ICA=Non Governmental Organization-International Cooperation Agency.

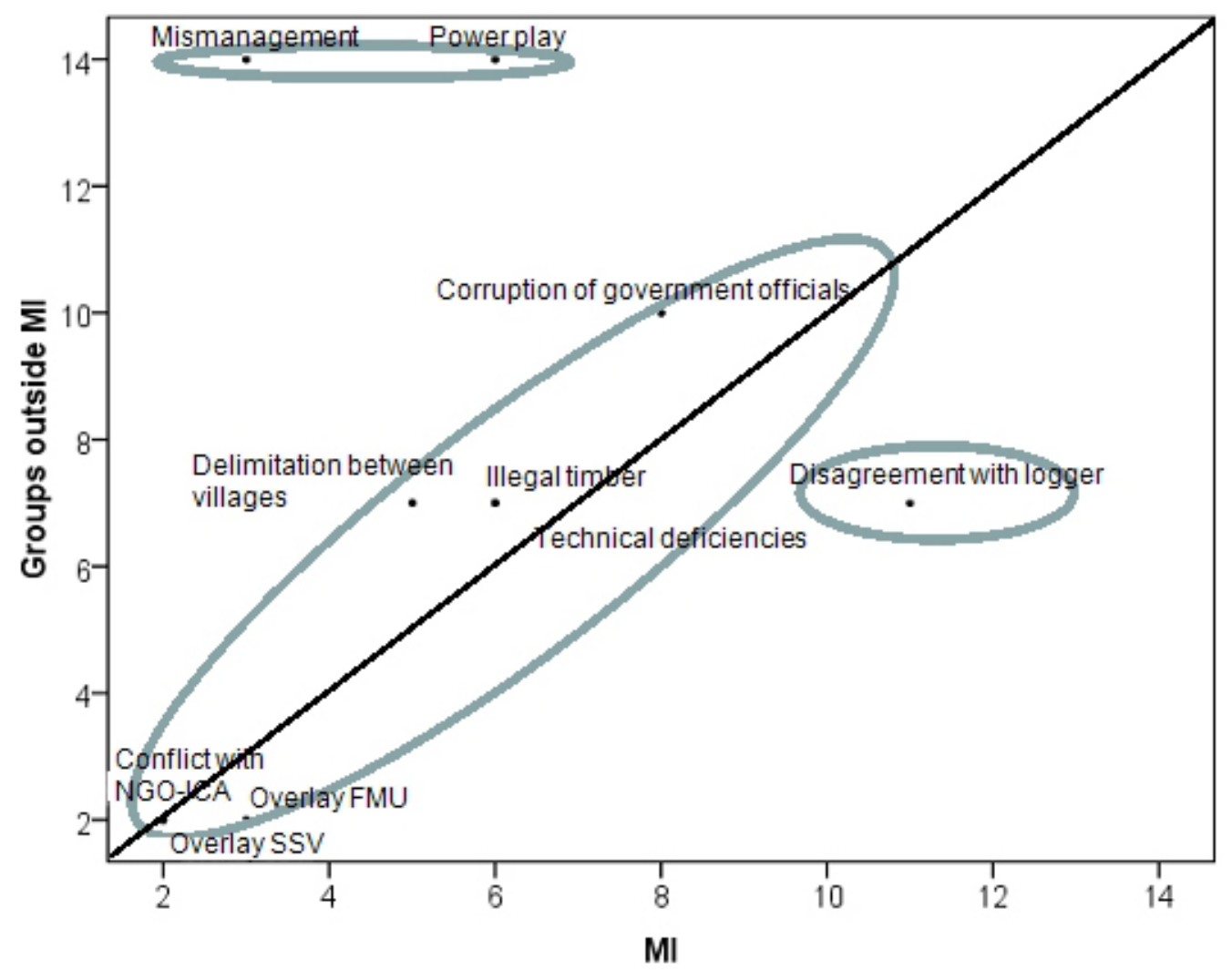

simple management plan agreed projects. Only two invested between 25 and $50 \%$, and three more than $50 \%$ of logging benefits.

To assess the influence of logging rent investments on the frequency of conflicts, we compared community forests with more than $25 \%$ of logging rent invested $(n=6)$ with community forests with less than $25 \%(\mathrm{n}=14)$. Following Wollenberg (1998), we assume that logging rent investments influence the frequency of conflicts since "the degree to which these benefits are significant and distributed equitably increases the motivations of people for collective action" (Wollenberg 1998:21). We consider here as "significant" when more than $25 \%$ of logging rent is invested in direct or indirect benefits for the community forest user groups.
Community forests with investments tended to have a lower conflict frequency score (Mann-Whitney U $=20.5 ; \mathrm{p}=0.076)$, although the variance was high (Fig. 7).

When external and internal conflicts were analyzed separately, sample size was reduced and the differences were not statistically significant. However, in both cases community forests with more than $25 \%$ of logging rent invested tended to have lower scores.

Conflict frequency can also be related to the total economic benefits of logging. Drawing on previous results (Ezzine de Blas et al. 2009), as a proxy of the capacity of community forest users to attain higher economic benefits, we used vertical 
Fig. 6. Frequency of investments types from community forest logging net revenues.

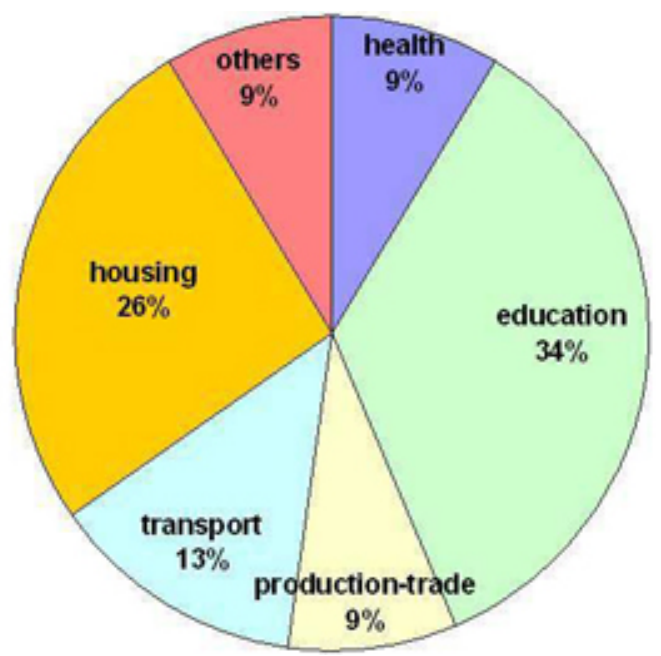

integration (Antinori and Bray 2005), i.e., an ordinal measure of the community's ability to integrate all forest activities ranking in our case from 1 , very low integration, to 7, very high. To perform this analysis, we classified the frequency of conflicts in three groups (Low for a frequency $<3$; medium for a frequency $3-4$; high for a frequency $>4$ ) and tested the behavior of vertical integration. Community forests with a low level of conflicts tended to have a consistently higher vertical integration. Community forests with medium and especially with a high frequency of conflicts tended to have a lower median vertical integration but a wider spread, from very low to very high vertical integration. This suggests that a trade-off exists between conflicts and the potential to obtain high logging benefits. Vertical integration depends, among other things, on a cohesive community well led by its community forest Management Committee. Consequently, low levels of conflict tended to be systematically associated with a high vertical integration. However, vertical integration also depends on forest resource endowment and distance to markets (Ezzine de Blas et al 2009). The potential to reap benefits from very valuable and well located community forests can also trigger Management Committee abuse and consequently community mistrust toward it, explaining highly conflictual and vertically integrated cases. However, partly because of the reduced size of our sample and the wide range of variation, the differences were not statistically significant.

\section{Outcomes of forest management and contextual factors}

General variables allowing a typology of local forest management initiatives were laid out following four dimensions: management aims, resource potential, potential of local social arrangements, and potential of political and economic context (Wollenberg 1998). Conflicts can emerge along all such dimensions. To explore possible links between the frequency of conflicts and the contextual characteristics of the community forests sampled, we selected seven variables derived from the literature on the governance of the commons (Wade 1988, Ostrom 1990, Baland and Platteau 1996, Wollenberg 1998, Agrawal 2001) that could apply to the Cameroonian case. These variables were: appropriate leadership, i.e., young, familiar with changing external environments, connected to local traditional elite and groups stratified by age and gender; coherence of interests; demographic pressure; incentives to local forest user groups, i.e., local people; community forest resource endowment, i.e., commercial potential of logging; objectives driving the management of the community forest; and the strength of local institutions (Table 3). 
Fig. 7. Ratio of investment in community facilities over total logging net revenues.

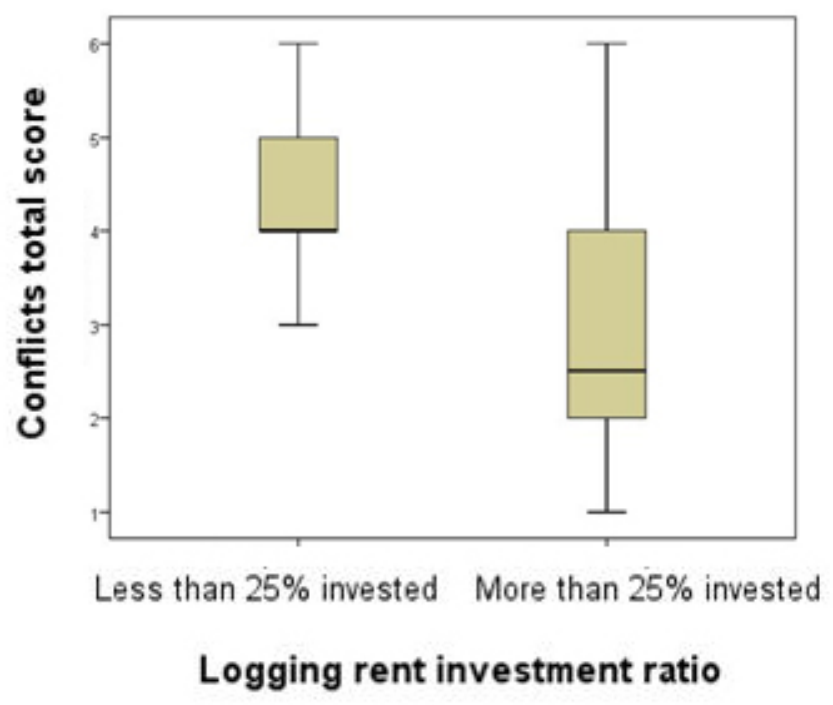

To explore the relationship between the variables, we performed a Principal Component Analysis for Categorical variables using SPSS 17.0. The model obtained is very robust (Cronbach-Alpha $=0.91$ ). Figure 8 shows, in two dimensions, the position of the centroids and of the eigenvectors of the variables. Centroids situated close to one another mean that positive and increasing values are associated. The position of eigenvectors shows the positive, negative, or nondependence of the variables' variance.

We distinguished three main groupings of community forests, defined by their association with a specific set of conditions. The first [I] includes three community forests under high population pressure, i.e., less than 1 ha of community forest per inhabitant, that have chosen to manage the community forest for conservation purposes. This appeared to be a plausible strategy given the relatively low potential of generating tangible per capita benefits. The main conflicts identified in this group were illegal extraction of forest resources and community forest delimitation disputes, both external conflicts.

The second group [II] represents 13 community forests whose surface area is not a constraint and where the commercial timber potential is medium or high, so that forest user groups have chosen commercial logging. This is the case of the Cameroonian forest lowland areas where the average population density is below 10 inhab $/ \mathrm{km}^{2}$ (Vande Weghe 2004). Mismanagement of logging rents, struggles for control of forest management decisions and illegal logging were the main conflicts associated with this group.

The third group [III] includes four community forests, with sufficient forest land but a medium to low commercial timber potential. This group is characterized by a strong coherence among peoples' interests, no mismanagement conflicts, strong incentives to forest user groups, and appropriate leadership. Community forests in this group appear to manage the forest more on the basis of social cohesion rather than as an immediate source of rent, which offers better conditions for continuing logging practices and diversification of income activities through nonlogging forest uses, such as nontimber forest products, ecotourism, etc.

These results sum up and reinforce the above findings that linked conflict with leadership, resource endowment, and investment of logging benefits. Conflicts around community forests were 
Table 3. Parameters to assess sustainable governance of Cameroonian community forests.

\begin{tabular}{lll}
\hline \hline Parameter & Proxy & Values \\
\hline Resource pressure & $\begin{array}{l}\text { Hectares of community } \\
\text { forest by inhabitant }\end{array}$ & 1=Low pressure; 2=Medium pressure; 3=High pressure \\
Purpose of management & $\begin{array}{l}\text { Objectives of resource } \\
\text { management }\end{array}$ & 1=Conservation; 2=Commercial logging \\
Productive potential & $\begin{array}{l}\text { Logging commercial } \\
\text { potential }\end{array}$ & 1=Low; 2=Medium; 3=High \\
$\begin{array}{ll}\text { Coherence of interests and } \\
\text { activities among managers }\end{array}$ & $\begin{array}{l}\text { Struggle for control of } \\
\text { management decisions }\end{array}$ & $\begin{array}{l}\text { 1=Conflict occurs (incoherence); 2=Conflict does not } \\
\text { occur (coherence) }\end{array}$ \\
Strength of local institutions & $\begin{array}{l}\text { Mismanagement of logging } \\
\text { rent }\end{array}$ & $\begin{array}{l}\text { 1=Mismanagement (unresponsiveness); 2=No } \\
\text { mismanagement (responsiveness) }\end{array}$ \\
Incentives to local people & $\begin{array}{l}\text { Ratio logging rent } \\
\text { investment }\end{array}$ & $\begin{array}{l}\text { 1=Low incentives (<25\% invested); 2=Strong incentives } \\
\text { (>25\% invested) }\end{array}$ \\
Appropriate leadership & Appropriate leadership & \begin{tabular}{l} 
1=No; 2=Yes \\
\hline
\end{tabular}
\end{tabular}

more common where local institutions are weak, where there is poor leadership, high potential for commercial logging, and only a small percentage of the logging rent is invested in community facilities.

\section{CONCLUSION AND RECOMMENDATIONS}

Community forests have been promoted as a way to provide financial benefits and development opportunities to rural forest communities. Although in theory they can offer a number of advantages such as job opportunities, our results show that only a small percentage of total community forest net benefits are invested in collective indirect, i.e., education and transportation, and direct benefits, i.e., housing improvements. Most are distributed among specific actors or interest groups and do not revert to community development.

A number of the systemic conflicts, i.e., illegal logging, corruption of government officials, and mismanagement, observed in half of our sample have a major impact on the viability of the implementation process. Some conflicts, e.g., poor technical capabilities, overlapping with FMUs, potential tensions with ICA-NGO, are context- specific. The frequency of conflicts was related to the proportion of net forest benefits shared collectively. Community forests with higher investment ratios tended to score lower in number of conflicts than community forests with lower investment ratios. These results support the work of Romainville (1999) and Julve et al. (2007), who found that the equal distribution of logging benefits is more important to build consensus within the community forest than the total amount of financial benefits received from logging. Equally, rewarding collective efforts has a positive impact on building confidence and trust, reducing the frequency of conflicts.

Actors with a strong interest in community forest resources, i.e., logging operators and government officials, are involved in systemic external conflicts. Moreover the nature of systemic external conflicts converges with the nature of systemic internal conflicts: appropriation of rents, i.e., mismanagement, and struggles over control of the community forest timber resources. The replication of this pattern suggests that these conflicts are part of a larger social context. At the national level, the generalized bad governance of Cameroonian institutions has created a self-reinforced social equilibrium in which 
Fig. 8. Total score of conflicts by investment ratio in community projects.

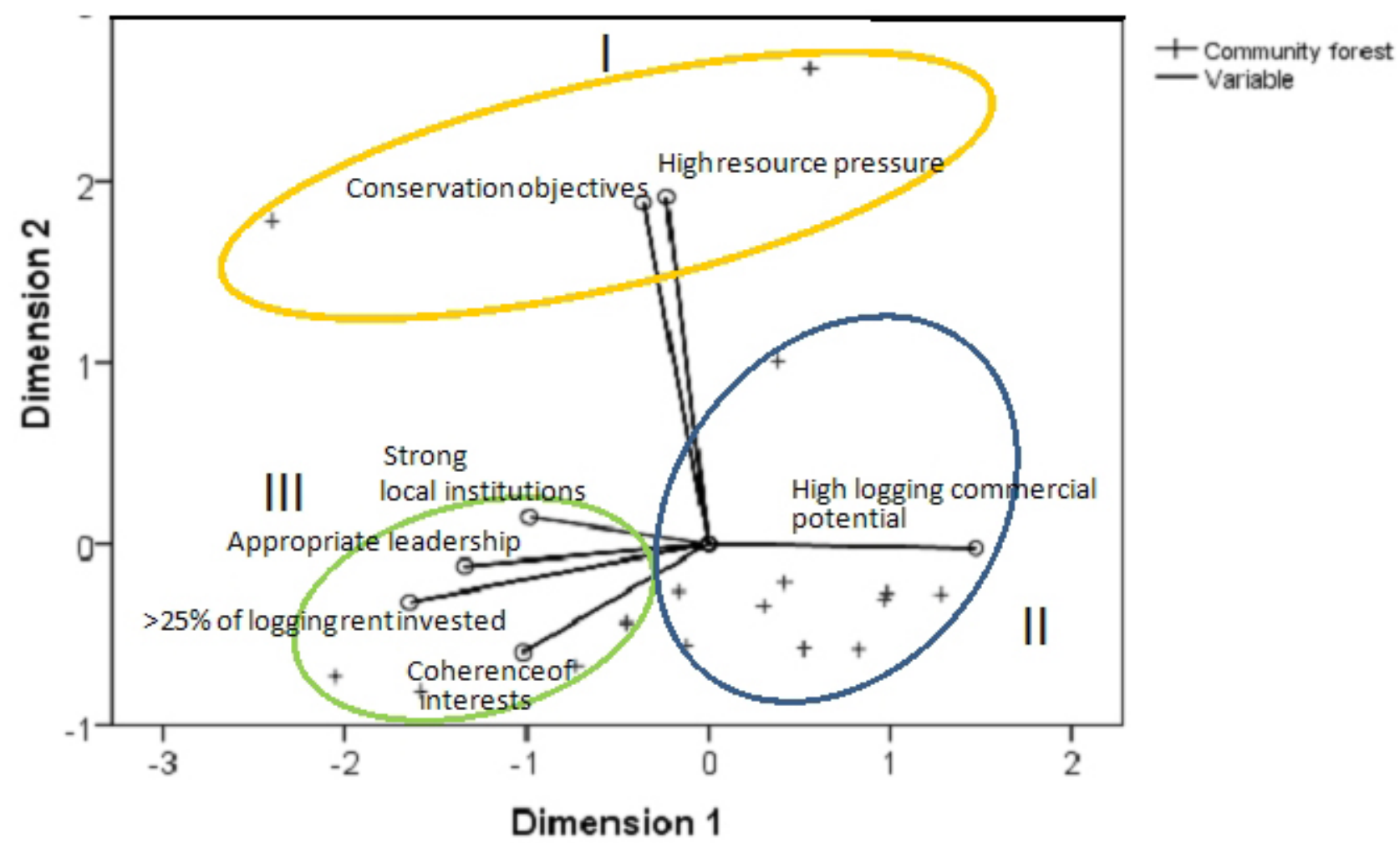

individualistic and opportunist strategies prevail from national to local level: a process also identified in other works (Azhar 1993, Robbins 2000).

Although ICA-NGO projects have mainly addressed technical and human capacity building, these conflicts appear to be peripheral, indicating their limited influence on the communities studied. Although this may be partly because of the assistance of ICA-NGOs, we suggest that development organizations have been unable to target some of the key obstacles related to local and national governance issues.

Disproportion in the frequency of conflict identification between the Management Committee and forest user groups outside it, mostly concerns negotiation, more frequently identified by the Management Committee, and mismanagement and power play, more frequently identified by user groups outside the Management Committee. This divergence expresses different roles and responsibilities, active managers vs. passive recipients, leading to possible mistrust and lack of transparency and communication among community forest members.

The appropriation of community forestry logging rent by the Management Committee, the first social group that has access to it, appears to be a frequent phenomenon. Whereas on one hand commercial logging of community forests is effectively being used to improve the basic needs of rural families, on the other hand, the total frequency of conflicts and in particular the high frequency of internal conflicts, are undermining its full potential. Conflicts also affect and are affected by vertical integration of community forests in the logging sector. This raises the question of what social conditions and other contextual factors are associated with conflicts and what could be done to minimize conflict. 
A number of clashing interests generate conflicts that are constraining the potential benefits of Cameroonian community forests. From external to internal actors, appropriation of logging rent and of management decisions are blocking community forest viability while at the same time fostering mistrust among actors. The analysis of the main external and internal conflicts and the identification of what association of variables could foster viable community forests suggest that downward accountability needs to be enhanced at both government and community levels. At government level, this could be achieved by enhanced participation in current initiatives for improving the transparency of the forest sector, e.g., the Forest Law Enforcement, Governance and Trade initiative, the control of illegal activities by an independent body called the "Forest Independent Observer", while at the same time punishing corrupt officials.

At the local level, ICA-NGO projects have traditionally focused on solving technical problems, designing management plans and forest inventories. Although most communities are aware of their limited technical skills, our study suggests that these are not considered to be a serious obstacle to proper management of the allocated forest. Although improving the technical skills of communities should be kept on the agenda, ICA-NGO should invest more in identifying and supporting credible leaders while at the same time designing tools for increasing the amount of total logging benefits shared and invested in collective benefits. To this end, we propose that an accountable community forest management committee should invest a significant percentage of logging net benefits in these kinds of family-shared and collective benefits. This could be achieved through the constitution of funds with the help of rural banks, and other types of incentives like tax reductions or the facilitation of community forest procedures if the spending of the benefits accrued from logging is transparently recorded and directed toward collective benefits by the Management Committee.

In the end, community forest conflicts are a reflection of similar disputes at a national level, where a much needed transparency, accountability, and participatory decision making have been proposed as a precondition for social and economic progress and local development schemes to succeed (Tacconi 2007, Sommerville et al. 2010). Our findings suggest that for this to be operational in the field, comprehensive national monitoring of community forest accountability would be needed, building on existing studies concerning governance indicators (Oyono et al. 2006). At the project level, these indicators should be quantified, monitored, and reported back to the government. The Forest Ministry would then have the means to propose clear incentives for community forest villages to be accountable, for example, linking renovation of the community forest management plan to achieving development objectives that were previously agreed on by all community forest families. Such development objectives could be part of a Local Development Plan or of other planning and monitoring instruments as proposed by Oyono et al. (2007). Finally, expecting clear, conflict-free, egalitarian, and sustainably managed community forests in the political and policy conditions that gave rise to them might prove to be delusive.

Responses to this article can be read online at:

http://www.ecologyandsociety.org/voll6/iss 1/art8/responses/

\section{Acknowledgments:}

We would like to thank community forest inhabitants who kindly received and accepted the research team, and for their confidence on how collective efforts would help them to improve their life standards. We would also like to thank the work of the anonymous reviewers that helped notably to improve the content of the paper.

\section{LITERATURE CITED}

Adhikari, B., S. di Falco, and J. C. Lovett. 2004. Household characteristics and forest dependency: evidence from common property forest management in Nepal. Ecological Economics 48:245-257.

Agrawal, A. 2001. Common property institutions and sustainable governance of resources. World Development 29(10):1649-1672.

Antinori, C., and D. B. Bray. 2005. Community forest enterprises as entrepreneurial firms: economic and institutional perspectives from Mexico. World Development 33(9):1529-1543. 
Assembe, S. 2003. Justice environnementale, gestion durable et manipulation des revenus forestiers: Une évaluation des impacts dans le SudCameroun. Center for International Forestry Research Report, Yaounde, Cameroon.

Azhar, R. A. 1993. Commons, regulation and rentseeking behavior: the dilemma of Pakistan's Guzara Forests. Economic Development and Cultural Change 42(19):115-129.

Baland, J. M., and J. P. Platteau. 1996. Halting degradation of natural resources: is there a role for rural communities? Clarendon Press, Oxford, England.

Brunner, J., and F. Ekoko. 2000. Cameroon. Pages 59-82 in J. F. Seymour and N. K. Dubash, editors. The right conditions: the World Bank, structural adjustment, and forest policy reform. The World Institute, Washington, D.C., USA.

Buchanan, J. M., R. D. Tollison, and G. Tullock. 1980. Towards a theory of rent-seeking society. Texas A\&M University Press, College Station, Texas, USA.

Cerutti, P., and L. Tacconi. 2006. Forests, illegality, and livelihoods in Cameroon. Center for International Forestry Research. Working Paper No. 35. CIFOR, Bogor, Indonesia.

Cheka, C. 2007. The state of the process of decentralisation in Cameroon. Africa Development 33(2):181-196.

Colfer, C., and D. Capistrano. 2005. Paths and pitfalls of decentralization for sustainable forest management: experiences of the Asia Pacific region. Pages 32-62 in C. Colfer and D. Capistrano, editors. The politics of decentralization. Forests, power and people. Earthscan, London, UK.

Crozier, M., and E. Friedberg. 1977. L'Acteur et le Système. Le Seuil, Paris, France.

Cuny, P., P. Abe'ele, G. M. Nguenang, R. Djeukam, S. Eboule, and E. Eyene. 2004. Etat des lieux de la foresterie communautaire au Cameroun. Ministère de l'Environnement et des Forêts, Yaounde, Cameroon.

de Jong, W., S. Ruiz, and M. Becker. 2006. Conflicts and communal forest management in northern Bolivia. Forest Policy and Economics 8:447-457.
Emerit, A., and G. Lescuyer. 2003. Trois étapes pour la gestion viable de la forêt camerounaise: comprendre, énoncer, concilier les logiques d'acteurs. Sociologies Pratiques 7:29-48.

Etoungou, P. 2003. Decentralization viewed from inside: the implementation of community forests in east Cameroon. World Resources Institute Environmental Governance in Africa Working Papers: WP \#12. [online] URL: http://www.wri.org/ publication/market-access-working-papers\#4906.

Ezzine de Blas, D., M. Ruiz-Pérez, J. A. Sayer, G. Lescuyer, R. Nasi, and A. Karsenty. 2009. External influences on and conditions for community logging management in Cameroon. World Development 37 (2):445-456.

Geschiere, P. 2004. Ecology, belonging and xenophobia: the 1994 forest law and the issue of "community". Pages 237-261 in H. England and F. Nyamnjoh, editors. Rights and the politics of recognition in Africa. Zed Books, London, England.

Iversen, V., B. Chettry, P. Francis, M. Gurung, G. Kafle, A. Pain, and J. Seeley. 2006. High value forests, hidden economies and elite capture: evidence from forest user groups in Nepal's Terai. Ecological Economics 58:93-107.

Julve, C., M. Vandenhaute, C. Vermeulen, B. Castadot, H. Ekodeck, and W. Delvingt. 2007. Séduisante théorie, douloureuse pratique: la foresterie communautaire camerounaise en butte à sa propre législation. Parcs et Réserves 62(2):18-24.

Karsenty, A. 2006. L'impact des réformes dans le secteur forestier en Afrique centrale. Pages 25-60 in R. Nasi, J.-C. Nguinguiri, and D. Ezzine-de-Blas, editors. Exploitation et gestion durable des forêts en Afrique Centrale. L'Harmattan, Paris, France.

Knight, J. 1992. Institutions and Social Conflict. Cambridge University Press, Cambridge, UK.

Krueger, A. O. 1974. The political economy of the rent seeking society. American Economic Review 54:291-303.

Kumar, S. 2002. Does "participation" in common pool resource management help the poor? A social cost-benefit analysis of joint forest management in Jharkhand, India. World Development 30 (5):763-782. 
Larson, A. M. 2005. Democratic decentralization in the forestry sector: lessons learnt from Africa, Asia and Latin America. Pages 32-62 in C. Colfer and D. Capistrano, editors. The politics of decentralization. Forests, power and people. Earthscan, London, UK.

Larson, A. M., D. Barry, and D. Ram Dahal. 2010. New rights for forest-based communities? Understanding processes of forest tenure reform. International Forestry Review 12(1):78-96.

Logo, P. B. 2003. The decentralized forestry taxation system in Cameroon: local management and state logic. World Resources Institute Environmental Governance in Africa Working Papers: WP \#10. [online] URL: http://www.wri.org/ publication/market-access-working-papers\#4904.

Magee, S. P., W. A. Brock, and L. Young. 1989. Black hole tariffs and endogenous policy theory. Cambridge University Press, Cambridge, UK.

Mermet, L., R. Billé, M. Leroy, J. B. Narcy, and X. Poux. 2005. L'analyse stratégique de la gestion environnementale: un cadre théorique pour penser l'efficacité en matière d'environnement. Natures Sciences Sociétés 13:127-137.

Ministère des Forêts et de la Faune (MINFOF). 2009. Manuel des procédures d'attribution et des normes de gestion des forets communautaires au Cameroun, Second edition. Ministère des Forêts et de la Faune, Yaoundé, Cameroun

Organisation for Economic Co-operation and Development (OECD). 1997. Evaluation of programs promoting participatory development and good governance. OECD, Paris, France. [online] URL: http://www.oecd.org/dataoecd/39/44 135019452.pdf.

Ostrom, E. 1990. Governing the commons: the evolution of institutions for collective action. Cambridge University Press, Cambridge, UK.

Oyono, R. P. 2005. The foundations of the conflit de langage over land and forests in southern Cameroon. African Study Monographs 26 (3):115-144.

Oyono, P. R., J. C. Ribot, S. Assembe, and P. B. Logo. 2007. Correctifs pour la Gestion Décentralisée des Forêts au Cameroun: Options et
Opportunités de Dix Ans d'Expérience. Center for International Forestry Research Governance Brief No. 33(f). Center for International Forestry Research, Bogor, Indonesia. [online] URL: http://w ww.cifor.cgiar.org/publications/pdf files/govbrief/ GovBrief0733F.pdf.

Oyono, R. P., J. C. Ribot, and A. M. Larson. 2006. Green and black gold in rural Cameroon: natural resources for local governance, justice and sustainability. World Resources Institute Environmental Governance in Africa Working Papers: WP \#22. [online] URL: http://www.wri.org/publication/marketaccess-working-papers\#5067.

Pacheco, P. 2005. Decentralization of forest management in Bolivia: who benefits and why? Pages 168-183 in C. Colfer and D. Capistrano, editors. The politics of decentralization. Forests, power and people. Earthscan, London, UK.

Ribot, J. C., A. Agrawal, and A. M. Larson. 2006. Recentralizing while decentralizing: how national governments reappropriate forest resources. World Development 34(11):1864-1886.

Robbins, P. 2000. The rotten institution: corruption in natural resource management. Political Geography 19:423-443.

Romainville, R. 1999. Les Pratiques associatives comme vecteur d'un " développement endogène ». Pages 573-590 in S. Bahuchet, D. Bley, H. Pagezy, and N. Vernazza-Licht, editors. L'Homme et la forêt tropicale. Editions du Bergier, Châteauneuf, France.

Siswanto, W., and W. Wardojo. 2005. Decentralization of the forestry sector: Indonesian's experience. Pages 141-151 in C. Colfer and D. Capistrano, editors. The politics of decentralization. Forests, power and people. Earthscan, London, UK.

Sommerville, M., J. Jones, M. Rahajaharison, and E. J. Milner-Gulland. 2010. The role of fairness and benefit distribution in community-based payment for environmental services interventions: a case study from Menabe, Madagascar. Ecological Economics 69: 1262-1271.

Tacconi, L. 2007. Decentralization, forests and livelihoods: theory and narrative. Global Environmental Change 17: 338-348. 
Turner, M. D. 1999. Conflict, environmental change, and social institutions in dryland Africa: limitation of the community resource management approach. Society and Natural Resources 12:643-658.

Vande Weghe, J. P. 2004. Forêts d'Afrique Centrale: la Nature et l'Homme. Lannoo, Tielt, Belgium.

Vermeulen, C. 1997. Problématique de la délimitation des forêts communautaires en forêt dense humide, Est-Cameroun. Pages 17-24. Procceedings of the Limbe Conference (Limbe, 1997). Tropical Forest Forum, Oxford, UK.

Wade, R. 1988. Village republics: economic conditions for collective action in South India. ICS Press, Richmond, California, USA.

Wollenberg, E. 1998. A conceptual framework and typology for explaining the outcomes of local forest management. Journal of World Forest Resource Management 9:1-35.

World Bank. 1998. Special program of assistance status report for Cameroon. World Bank, Washington, D.C., USA.

${ }^{[1]}$ Decree no. 95/531/PM of August 23.

${ }^{[2]}$ Ministerial letter no. 0677/LC/MINEF/DF/CFC, $23^{\text {rd }}$ of February 2001.

[3] Forest Law decree no. 95/531/PM specifies community forests functioning. 